日本結晶学会誌 28,209 (1986)

[最近の研究から]

反射電子回折におけるステップの効果

山梨大学・教育学部 川 村 隆 明

Takaaki KAwAmura : The Effect of Surface Steps on RHEED.

The effect of surface steps on RHEED is described on the basis of calculated intensities based on multiple scattering theory from periodic arrays of steps. The results show that multiple scattering theory is necessary to interpret intensities even qualitatively. For example, 1) the intensities are quite different from those by single scattering theory, and 2) the intensities strongly depend on the incident beam azimuth to the step edges. In application, the intensity variations from stepped surfaces as a function of the number of atoms in the topmost layer are used to analyse RHEED intensity oscillations during molecular beam epitaxy. [J. Cryst. Soc. Jpn. 28, 209 (1986)].

\title{
1.はじめに
}

反射電子回折 (RHEED) は低速電子回折 (LEED) などとともに表面の構造解析の有力 な手段として知られている1). RHEED では 10〜 $100 \mathrm{keV}$ の電子を表面にすれすれの角度 $\left(0.5 \sim 5^{\circ}\right)$ で入射させることで結晶内への侵入距離を小さくし, 表面からの回折を大きくし， 表面構造の情報を多くしている.このことから, もし表面近くにステップなどの表面原子層 の乱れがある場合には，RHEED はこの乱れに対しても敏感になることが予想される（第 1 図). 表面構造を定量的に解析するときには，表面の粗さの効果は当然重要になる. またス テップ表面は触媒などの面からみても興味があり, ステップの構造, ステップの上面と下面 の原子位置変化など固有のおもしろさがある.RHEEDが表面のステップに敏感であること を利用すればこれまでの LEED による研 究2) 以上にステップ表面が解析できることに なる。

我々は, ここ 2,3 年 RHEED に対する 表面のステップの効果を多重散乱理論に基づ く計算によって調べ，1）ステップの効果が ステップ端と入射電子方位との相互の位置関 倸によって大きく違うこと，2）運動学的 1 回散乱理論による結果と違うこと, 従って Henzler らによる LEED でのステップ構造 の解析 ${ }^{2}$ には問題があること， 3 ）応用とし て, 分子線ェピタクシー (MBE) 成長中の RHEED 強度の振動をうまく説明できるこ とを明らかにしてきた。
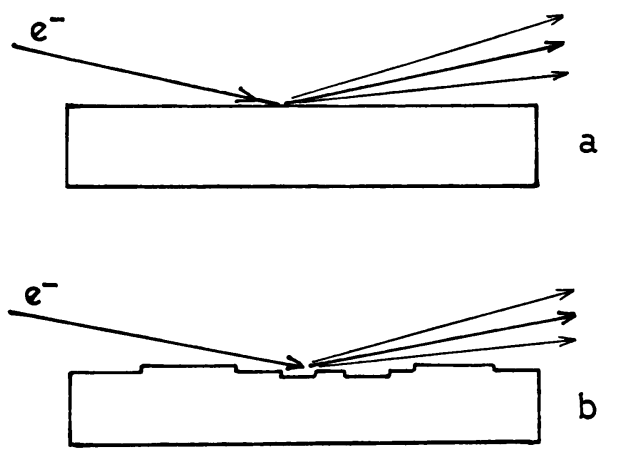

第1図 RHEEDにおける入射ビームと結晶 表面の位置関係. 入射視射角は $0.5^{\circ}$ から $5^{\circ}$ 程度であるので, (b) のよう に表面にステップがあると強度に与 える効果は大きい. 
以下ではこの結果を中心にして RHEED におけるステップの効果を述べることにする.

RHEED に使われている電子ビームの大きさは大体 $0.1 \mathrm{~mm} \phi$ である．これを表面に照射 すると, 入射角 (RHEED では表面からの角度視射角が用いられる) を $\theta$ とするとき, ビー ムは入射方向に伸びた長円形に近いものとなる. 結晶表面での大きさは $\theta \approx 1^{\circ}$ のとき, $6 \mathrm{~mm}$ $\times 0.1 \mathrm{~mm}$ となる.この範囲で表面が平坦であれば良いことになるが，実際にこのような広 い範囲にわたって平坦な面を得ることは容易ではない，八木らの REM (反射電子顕微鏡)像 をみても ${ }^{3)} \mathrm{Si}(111)$ 辟開面で平坦な部分は数千オングストロームから数ミクロン程度である. 数ミクロン以上の範囲で平坦であれば, 回折の上からは平らであるとして問題ない. 回折に 影響するのは電子の可干渉距離 (RHEED では 100 500Å) の範囲のステップであるが，こ れとて, 多くの金属の表面ではしばしば存在している.

このような表面のステップを問題にするのは現在の計算では容易ではない。そこで以下で は, まず数 $10 \AA ̊$ 程度の間隔でステップがあるような, ステップ密度が大きい表面からの RHEED 強度を問題とする.

\section{2. 理論的基桮}

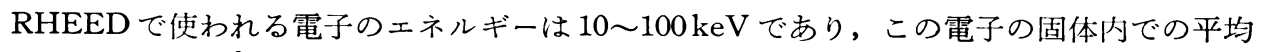
自由行程は約 $100 \AA$ であるので, 表面の原子による散乱は 1 回散乱として近似して良いと思 われるかも知れない.しかし，第 2 図に示し たように，RHEEDでは電子が表面すれすれ に入射するため, 電子は表面層の原子を串刺 しにした形で通過する.串刺しにされた原子 の数は 50〜100 個になる. 電子は表面の 1 層 内の原子の 100 個近くと相互作用することに なる.言いかえれば電子は 100 個近くの原子 によって散乱されてきたとみなくてはならな いのである．このことは表面ステップがある ときにもあてはまる，ステップを作っている 原子は 2 層あるいはそれ以上の表面層に含ま れている原子から成るが，それらの原子の 100 個近くと電子は相互作用する.さらに結 晶表面は 1 層から成るものではなく, その下 にバルクの原子層が規則的に並んでいるので, このバルクからの電子の散乱についても考兄 なくてはならない.ステップからの電子の散 乱を正しく見積る上でも，バルクからの散乱 を考える必要がある.

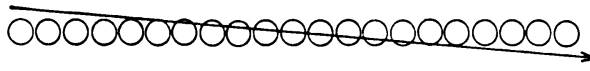

第 2 図 RHEED の電子線が一つの層内の原 子を横切る様子を示す模式図. 実際 には 50 から 100 個の原子を串刺し にする。

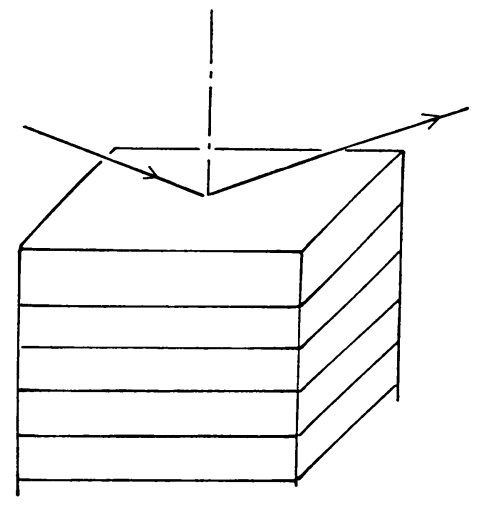

a

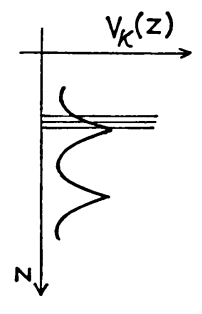

b

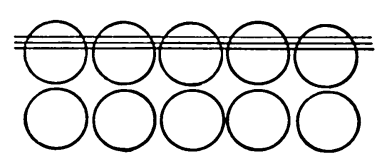

c
第3 図多重散乱理論の取扱いを示す模式図. (a)結晶を表面に平行な原子層に分け， (b)原子のポテンシャルをさらに細かい スライスに分ける. (c)スライスによっ て切断された原子の様子. 
そこで電子と結晶原子との多重散乱を計算する必要がある．計算法は Maksym と Beeby ${ }^{4}$ によるもの Ichimiya ${ }^{5)}$ によるものとがあるが，二つの方法は基本的には同じである．この 方法ではまず結晶を表面に平行な層に分ける（第 3 図(a)). 各層内では原子が周期的に配列 していて，表面に平行な二次元面内において，二次元逆格子ベクトル $\boldsymbol{g}$ が与えられるもの とする.こうすると，原子のポテンシャル $V(r)$ は，座標 $r$ の表面平行成分を $\boldsymbol{\rho}$, 垂直成分 を $z$ として,

$$
V(\boldsymbol{r})=\sum V_{g}(\boldsymbol{z}) \exp (\boldsymbol{i g} \cdot \boldsymbol{\rho})
$$

といら形にフーリエ級数展開できる。こうしてできた $V_{g}(z)$ は結晶内で第 3 図(b)に示すよ らな形になっている. $V_{g}(z)$ の形は $\boldsymbol{g}$ の值, 結晶の種類による. 通例 $V_{g}(\boldsymbol{z})$ は電子の原子 による散乱因子6) を逆フーリェ変換して求められる.

次に一つの層内での多重散乱を解くのに, 層を表面に平行な薄い層（スライス）に分割し, $V_{g}(z)$ をポテンシャルとするシュレーディンガー方程式を数值積分していく（第 3 図(c)). 1 枚のスライスの厚さ $\Delta z$ が積分のきざみになる. この方法の原理は透過型の電子回折で知 られているマルチ・スライス法7) と同じである．RHEEDでは反射強度を求める必要がある ので, 各スライスでの回折波 $(\boldsymbol{g})$ ごとの透過係数と反射係数とが求められる.これを積み重 ねると一つの原子層による反射および透過係数が求まり, さらに結晶をこの原子層の積み重 ねと考えれば結晶全体の反射および透過係数が求められる.

この理論を用いて，RHEED におけるステップの効果をとり入れようとするとステップも 周期的でなくてはならない，現実の多くのステップは非周期的であるが，周期的であるとし て計算した結果については以下で述べる．後で分かるように RHEED 強度に対するステッ プの効果の基本的性質は十分に理解できるのである.

\section{3. 周期的ステップ表面からの RHEED 強度}

計算に用いた周期的ステップのようすを第 4 図に示す.各ステップの高さは 1 原子層分で， 周期はバルク構造のまま切断された平坦な表面に比べ, 図の [10] 方向に $N_{p}$ 倍になってい る. [01] 方向の周期に変化はない. ステップ上面すなわち第 1 層の原子数は [10] 方向に $n_{0}$, 従って第 1 層の原子密度は平坦な面に比べ $n_{0} / N_{p}$ になっている. 第 1 層の原子位置はバルク 構造を延長したところに置き, 表面での格子 緩和, 再構成構造などの効果については考え ないことにする.モデル計算は $\mathrm{Al}(001)$ 面 について行ったものを以下で示す8,9). 計算で は12 原子層までを考え，反射回折強度がこ れ以上層の数を増しても変わらないことを確 めているので, 結晶表面から回折されてくる 強度を多重散乱を全て取り入れて求めている ことになる。

第 5 図(a)には平坦な面からの RHEED 鏡 面反射強度を視射角 $(\theta)$ を变化させて計算し たものを示す．この強度 - 視射角曲線をロッ キング・カーブとよぶ. 方位角は [10] (三次 元の結晶方向では [110]) である. 強度のス

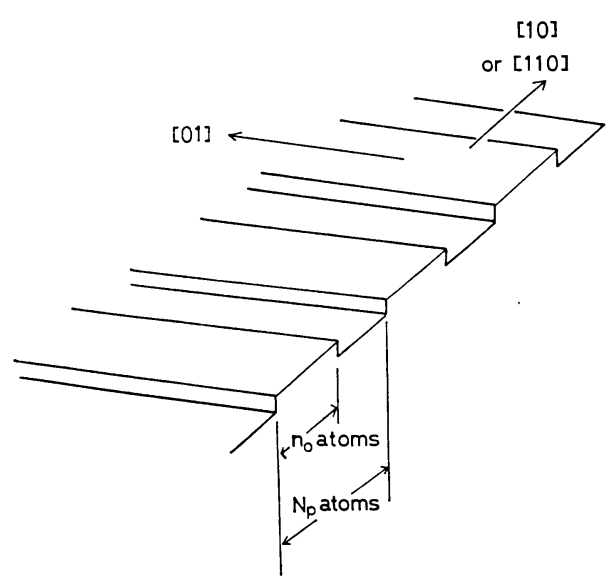

第 4 図 多重散乱に用いた周期的ステップの 模式図. $\mathrm{Al}(001)$ について示す. 


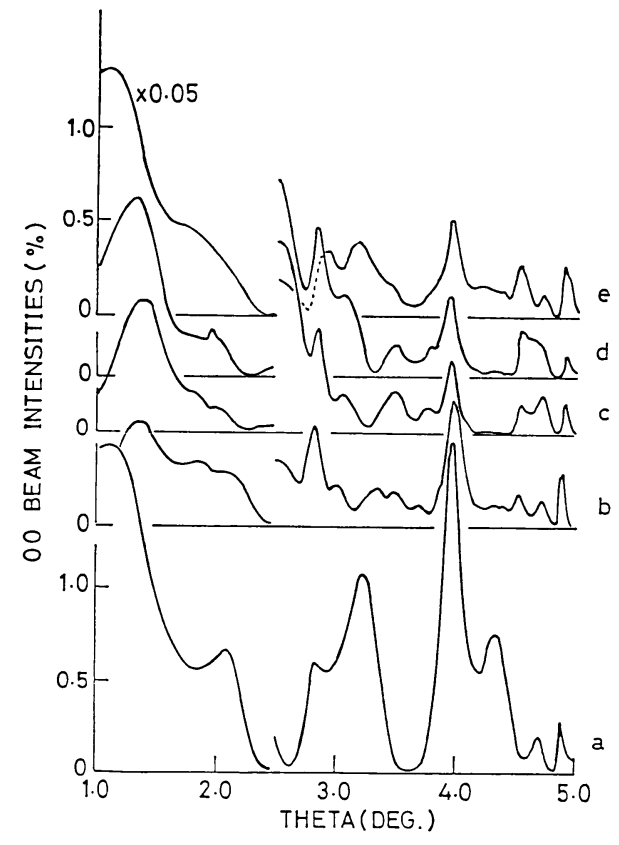

第 5 図鏡面反射強度ロッキング・カーブ. (a) 平坦な面, (b) $n_{0}=1$, (c) $n_{0}=2$, (d) $n_{0}=3$, (e) $n_{0}=4$, (b)-(c) では $N_{p}=5$.

ケールは $\theta$ の小さいところで 0.05 倍してあ る.曲線にみられるいくつかのピークは二次 ブラッグ・ピーク, 共鳴ピークなどである.

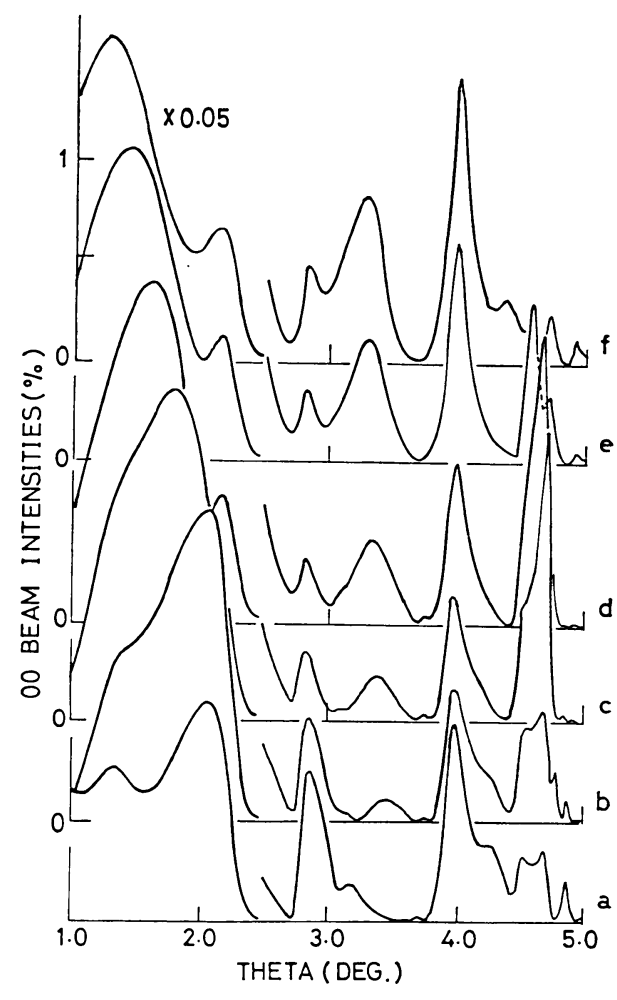

第 6 図 鏡面反射強度ロッキング・カーブ. $N_{p}=7$ とし，(a)から(f)へ $n_{0}=1$ から 6 へと変化させたもの.

次にステップの周期を 5 倍にし $\left(N_{p}=5\right), n_{0}$ を変化させたときのロッキング・カーブを第 5 図 (b)-(e) に示す. (b) は $n_{0}=1$, (c) は $n_{0}=2$, (d) は $n_{0}=3$, (e) は $n_{0}=4$ のときである. 方位角は [01] で入射ビームとステップ端とが平行である. 図(b)-(e)では (a)に比べ全体的 に著しい強度の減少がみられる，同様なことは整数次反射 10 などにもみられる．これはス テップがあるため, 電子ビームが他の方向に散乱され——今の周期的ステップの場 合には $1 / N_{p}$ などの分数次の回折波, 一般には散漫散乱が生じ——鏡面反射, 整数次反射の強度が 減少すると考えられる。

第 6 図 (a)一(f)には入射方位が [10] すなわちステップ端に垂直なとき， $N_{p}=7$ とし $n_{0}$ を 1 から 6 まで变化させたときの鏡面反射ロッキング・カーブを示す.この場合全体的な強度 は平坦な場合（第 5 図(a)）に比べてあまり変化せず，またピーク位置についても変化しない ものが多い. ピーク強度は $n_{0}$ の関数として变化している. たとえば $\theta=4^{\circ}$ のピークについ てみると, 平坦な面 $\left(n_{0}=1\right)$ から $n_{0}$ が増加するとピーク強度は減少し, $n_{0}=3$ のところで 最小となる.さらに $n_{0}$ が増加すると強度は增加する. 一方 $\theta=4.7^{\circ}$ のピークでは $n_{0}$ の変 化に対するピーク強度の振る舞いはちょらど逆になっている。これらピーク強度の变化は各 ピークが生じる散乱過程に依存しており, 多重散乱計算によってはじめて得られるものであ る. 表面が粗くなると強度が小さくなるといら光学的なモデルは成り立たない。

第 6 図のロッキング・カーブではもら一つ大切なことがある.この入射方位では, $N_{p}$ す

28. 3-14 
なわちステップの周期によらず $n_{0} / N_{p}$ の比に よって強度が決まるのである. ステップ端が 入射ビームに垂直であれば，そのステップ自 体は周期的に配列していなくとも $n_{0} / N_{p}$ の值 が同じであれば，ロッキング・カーブは同じ ものとなる.言い換えれば, ステップの上面 テラスと下面テラス上の原子の数の比が強度 を決めていることになる。

入射方位がステップ端に平行なときには， $N_{p}$ 倍の周期による分数次反射 $\left(1 / N_{p}, 2 / N_{p}\right.$, ……) は多重散乱による影響を強く受ける. 一例を第 7 図に示す. 同じ $\mathrm{Al}(001)$ で $N_{p}=5$, $n_{0}=1$ としたときの $1 / 5,0$ 反射のロッキング・ カーブである.(a)は 1 回散乱近似によるも の，(b)は多重散乱理論によって計算したもの である.(a)では結晶表面の第 1 層に 1 個の原 子列が下地原子の 5 倍の周期で並んでいて，

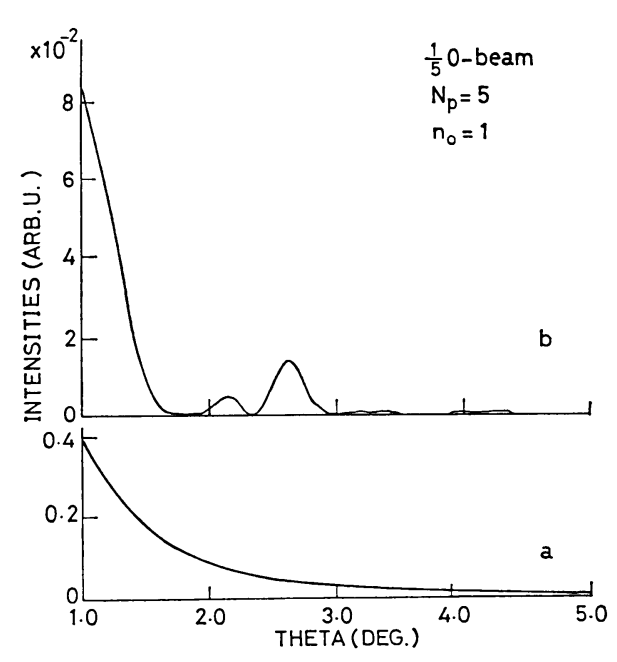

第 7 図 1/5, 0 反射のロッキング・カーブ. $N_{p}=5, n_{0}=1$. (a) 1 回散乱近似, (b)多重散乱計算によるもの. 第 2 層目以下はバルクと同じ構造であるため視射角を大きくしていくと強度は単調に減少す る. 一方(b)では全く同じ表面構造であって, 多重散乱により強度の增減が生じている.ピー ク位置は第 5 図(b)の鏡面反射のピークと関係している.

分数次反射について系統的に調べてみると, 分数次反射どうしの相対強度比も 1 回散乱近 似と多重散乱によるものとでは差が大きいことが分かった.

これらの結果は Henzler 等が LEED で行ってきた 1 回散乱近似によるステップ構造の解 析結果 ${ }^{2)}$ とは異なっており，少なくともRHEED においては多重散乱をとり入れた計算が 必要であることを示している。ここで得られた多重散乱による計算は，これまでのステップ 構造の決定に大きな疑問を投げかけている.

\section{MBE 成長中の RHEED 強度振動への応用}

最近人工格子の作製と関連して，MBEによって結晶層を 1 層ずつ成長させることが行わ れている ${ }^{10-12)}$. この MBEによる層成長のモニタ一の最も有効な手段は RHEED 強度変化 を使ったものである。第 8 図に GaAs $(001)$ 上の GaAs 成長中の RHEED 強度変化を示 す ${ }^{10)}$. 横軸は時間であり, 結晶表面に付く原子の数と考えられる. 縦軸は鏡面反射強度であ る. 強度のピークから次のピークまでの時間は, Ga-As の 1 層が成長する時間に対応して いる. この RHEED 強度振動を用いると成長中の層の数をその場観察できるので非常に有 用である.

この RHEED 強度解析は二つの方法で行われている．一つはランダムに原子が 付いてい って1層ができるものとし，1層内にランダムな原子分布を仮定し，この原子分布からの RHEED 強度計算を 1 回散乱近似で行らものである ${ }^{13,14)}$ 。もら一つは, 上に述べてきた, 周 期的ステップからの RHEED 強度計算を用いて行らもので, 15), この場合には多重散乱を考 えている．ここでは後者について述べる，といらのは，飛んでくる原子は表面にランダムに くるが, 表面の原子が規則格子を作っているために, 飛んできた原子が表面上を移動し, 層

28. 3-15 
成長の途中では長方形ないしは基盤表面原子の対称性を反映した島状の原子層を作りながら 1 層が形成されると考えられる場合が多いからである ${ }^{10,15,16)}$. また第 3 節で述べたように,

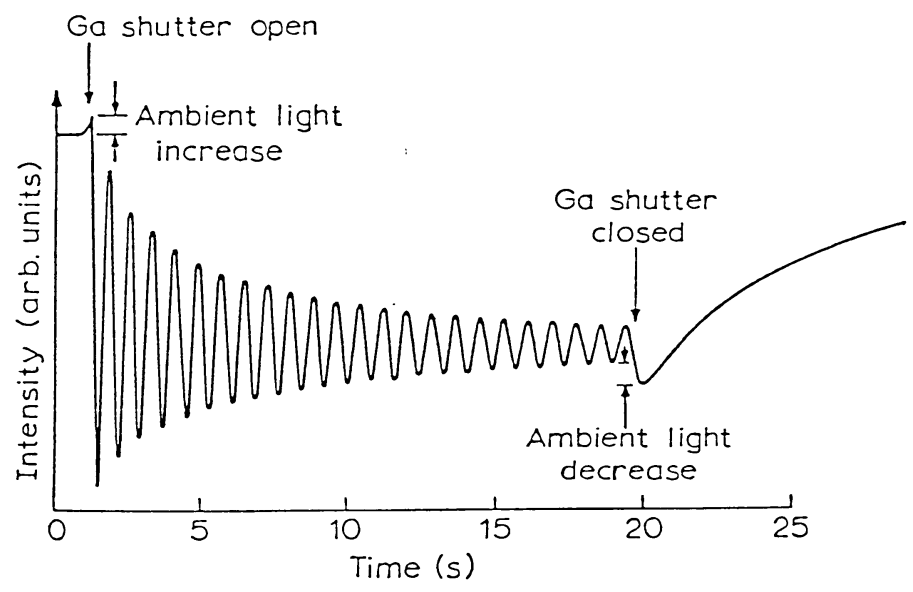

第 8 図 $\mathrm{GaAs}(001)$ 上に $\mathrm{As}_{2}$ 雾囲気中で $\mathrm{Ga}$ を飛ばしたときの鏡面 反射強度変化. Ga を飛ばし始めると RHEED 強度は振動し始 め, Gaを止めると，Asによって安定化された表面になる。

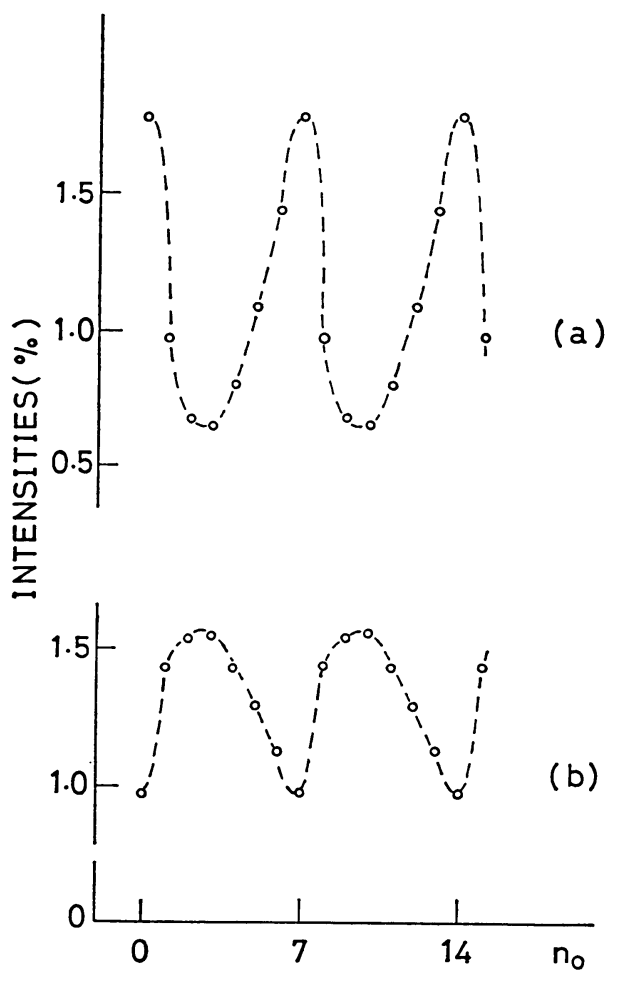

第 9 図 ステップ表面からの RHEED 強度 （第 6 図）から得られた $n_{0}$ に対する 鏡面反射強度变化 (a) と 01 反射の強 度变化 (b). $\theta=4^{\circ}$.

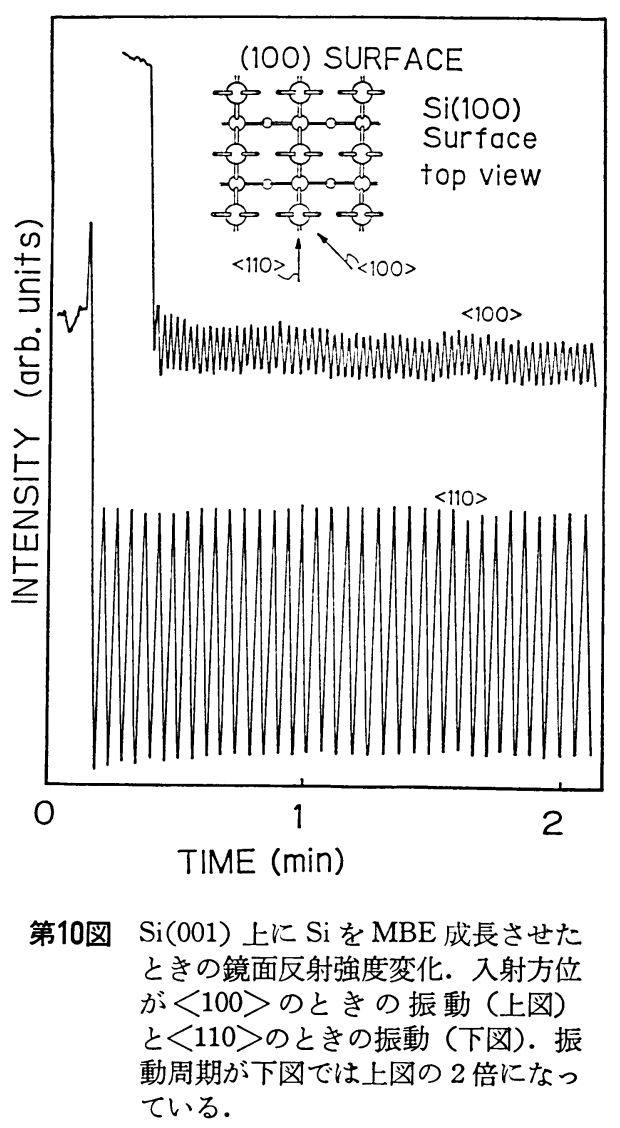

28. 3-16 
ステップ端が入射ビームに垂直になっていれば，不規則に並んだステップでも規則的なステ ップでも RHEED 強度は同じになるからでもある．入射角 4 ○ のときのピーク（第 6 図） 高さを $n_{0}$ の関数としてプロットすると第 9 図のようになる. (a)は鏡面反射強度，(b)は 01 ス

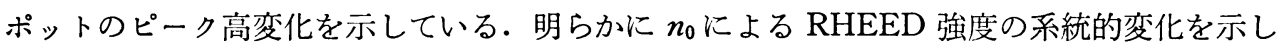
ている. 鏡面反射強度は平坦な表面に対して最大値になり， $n_{0}=3$ のとき最小值となってい る. 01 スポットの強度変化は 鏡面反射のそれとは逆に平坦な表面に対して強度最小となっ ている.このような変化は, 物質は全く異なるが GaAs の成長の場合に実験的に見出されて いる(0).この変化は鏡面反射を作る 00 ロッドの波と 01 ロッドの波の間の干渉によって生じ ており，多重散乱を用いて初めて理解できるものである ${ }^{9)}$.

もら一つ多重散乱による解析がうまくいった例に $\mathrm{Si}(001)$ 上の $\mathrm{Si}$ の MBE 成長がある. この場合入射ビームが [100] 方位では単原子層を周期とする RHEED 強度振動が鏡面反射 で見られるのに対し，[110] 方位では 2 原子層を周期する振動がみられる(第 10 図 $)^{15)}$. 同じ 成長が入射ビームの方向によって, RHEED 強度振動では異なる周期として観测されるので ある.これは第 11 図のような長方形の島状の成長を仮定し, ステップ表面からの RHEED

(a)

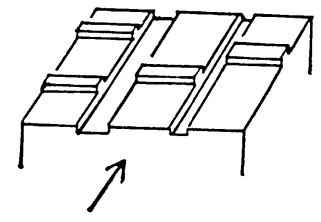

(b)

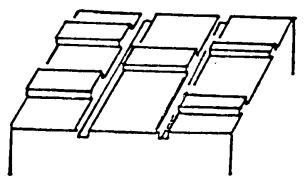

(c)

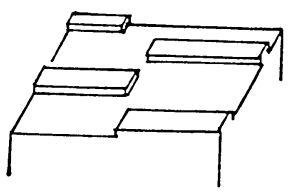

(d)

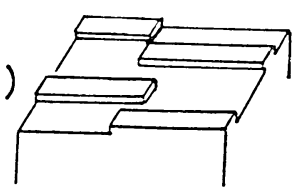

(e)

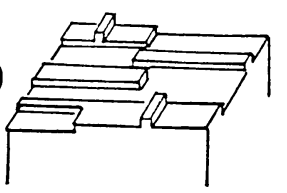

(f)

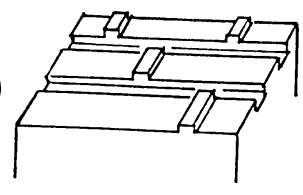

(g)

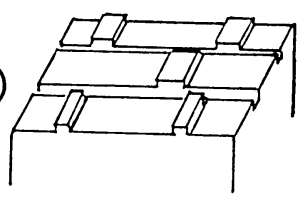

(h)

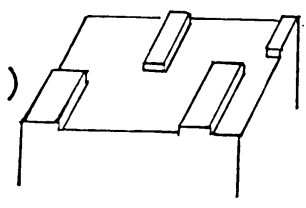

(i)
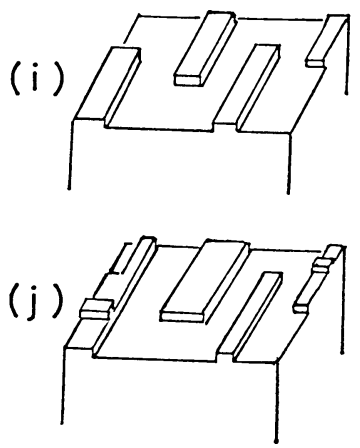

第 11 図 MBE 成長中の RHEED 強度振動の入射方位依存性（第 10 図） を説明するための, MBE 成長中の単原子層島の形成模式図. 
強度の結果と組み合せるとらまく説明できることが分かった ${ }^{16)}$. 詳細は述べないが，この結 果は, 第 10 図のような強度振動を示す $\mathrm{Si}(001)$ 表面は, 平坦なときには単一ドメインにな っていることを示している ${ }^{17,18)} . \mathrm{Si}(001)$ は通常 $2 \times 1$ と $1 \times 2$ の二つのドメインからでき ていて, 単一ドメインの表面を得ることは困難とされてきた.上の結果は, これまでの常識 を変えるものであり，ステップからの RHEED 強度計算が明らかにした成果の一つである.

\section{5. まटめ一一現実のステップへ}

これまで RHEED の多重散乱理論が使える 周期的ステップについての 計算結果を示して きた。これと現実の多くのステップとはまだまだかけ離れている. 逆に非周期ステップの極 限を考えてみよう・ステップを第 4 図のように一方向に規則的に並んだ原子列から成るとし， ステップ端に垂直な方向（図では［10] 方向）では不規則にこの原子列を並べるこうする と, この表面構造に対する逆格子はステップ端に垂直な方向に広がった逆格子面となり, 電 子の入射方位が逆格子面に垂直なとき，この面とェワルト球との交線は円となる．すなわち 円状の像が観測されるはずである。これに対応する像はすでに三宅と早川により ZnS(110) で実験的に報告されている円状像 ${ }^{199}$ と考光られる．彼らはこの円状像の原因を不明としてき たが，不規則に並んだステップといらモデルは一つの説明を与えている20). 他にも円状像は $\mathrm{GaAs}(001)$ からも得られている(10)。一方, 同じ不規則ステップ表面に対して, もし入射方 位が逆格子面と平行であれば，何本かのストリーク（表面に垂直方向に伸びた棒状の像）が 得られる.このストリークも円状像が出る同じ表面で, 入射方位を変えたときに観測されて いる19). 円状像, ストリークは表面での原子配列の規則性を知る上では大切であるが，その 定量性となると，今のところ 1 回散乱近似以外に方法がなく，まだ不十分である.

一見理想化しすぎているように思われた規則的ステップからの多重散乱計算から, 表面ス テップが RHEED 強度に与える効果の基本的性質を理解することができた。一つはステッ プの効果はそれだけ単独に現われるのではなく, 下地結晶との間の多重散乱を通して強度が 決まってくる点である.これは明らかに従来の 1 回散乱による解析の限界を示している.二 つめは入射方位とステップ端との相対位置関係によって強度に著しい差が生じることであり， これも多重散乱理論で初めて導かれるものである. 三つめは入射方位とステップ端が垂直な ときは規則的ステップからの強度がある程度まで不規則なステップでも同じになる点である.

また MBEへの応用では，GaAs (001) では単層の島を作りながら 1 層ができる成長機構 であることを明確にするのに役立ち, Si (001) では単一ドメイン発見にも役立った.

我々の知りたい現実の表面, 現実のステップは, 周期的ステップと完全に不規則なステッ プの中間, あるいはそれらの混ったものであらう. 現実の表面を知るというゴールへはまだ 相当の距離があるが，着実に進み始めたことは明らかである．ステップ構造の解析の重要さ， 表面構造解析の重要さを考劣るとき，RHEEDを用いたステップ構造の研究は今後の大きな 課題となることであろう.

\section{文献}

1) 井野正三 : 日本結晶学会誌 23, 197 (1981).

2) M. Henzler : Appl. Surface Sci. 11-12, 450 (1982).

3）八木克道, 高柳邦夫, 谷城康真 : 日本物理学会誌 37, 994 (1982).

4) P. A. Maksym and J. L. Beeby : Surface Sci. 110, 423 (1981).

5) A. Ichimiya : Jpn. J. Appl. Phys. 22, 176 (1983).

28. 3-18 
6) P. A. Doyle and P. S. Turner : Acta Cryst. A 24, 390 (1968).

7) J. M. Cowley : Diffraction Physics, North-Holland (1975).

8) T. Kawamura, P. A. Maksym and T. Iijima : Surface Sci. 148, L671 (1984).

9) T. Kawamura and P. A. Maksym : Surface Sci. 161, 12 (1985).

10) J. H. Neave, B. A. Joyce, P. J. Dobson and N. Norton: Appl. Phys. A 31, 1 (1983).

11) T. Sakamoto, H. Funabashi, K. Ohta, T. Nakagawa, N. J. Kawai and T. Kojima : Jpn. J. Appl. Phys. 23, L657 (1984).

12) J. M. Van Hove, C. S. Lent, P. R. Pukite and P. I. Cohen : J. Vac. Sci. Technol. B 1, 741 (1983).

13) S. V. Ghaisas and A. Madhukar : J. Vac. Sci. Technol. B 3, 540 (1985).

14) A. Madhukar and S. V. Ghaisas : Appl. Phys. Lett. 47, 247 (1985).

15) T. Sakamoto, N. J. Kawai, T. Nakagawa, K. Ohta and T. Kojima : Appl. Phys. Lett. 47, 286 (1985).

16) T. Kawamura, T. Sakamoto and K. Ohta : Surface Sci. 171, L 409 (1986).

17) T. Sakamoto, T. Kawamura and G. Hashiguchi : Appl. Phys. Lett. 48, (1986) in press.

18) T. Sakamoto and G. Hashiguchi : Jpn. J. Appl. Phys. 25, L 78 (1986).

19) S. Miyake and K. Hayakawa : Acta Cryst. A 26, 60 (1970).

20) T. Kawamura, M. Hasebe and P. J. Dobson : J. Phys. Soc. Jpn. 54, 3675 (1985). 